\title{
Kekebalan dan Keamanan setelah Mendapat Imunisasi Hepatitis B Rekombinan pada Anak Remaja
}

\author{
Eddy Fadlyana, ${ }^{*}$ Kusnandi Rusmil, ${ }^{*}$ Novilia S Bachtiar ${ }^{* *}$ \\ *Departemen Ilmu Kesehatan Anak, Fakultas Kedokteran Universitas Padjadjaran, Rumah Sakit Dr \\ Hasan Sadikin, Bandung, ${ }^{* *}$ PT Bio Farma, Bandung.
}

\begin{abstract}
Latar belakang. Berdasarkan riwayat implementasi program imunisasi Hepatitis B di Jawa Barat, diperkirakan anak periode remaja akhir (15-18 tahun) belum terlindungi terhadap infeksi Hepatitis B.

Tujuan. Menilai kekebalan dan keamanan pasca imunisasi 3 dosis vaksin Hepatitis B rekombinan pada anak remaja sehat yang belum pernah mendapat imunisasi Hepatitis B.

Metode. Penelitian intervensi dengan label terbuka terhadap remaja usia 15-18 tahun yang belum pernah mendapatkan imunisasi Hepatitis $\mathrm{B}$, diberikan 3 dosis $(1,0 \mathrm{ml}=20 \mu \mathrm{g}$ of $\mathrm{HBsAg})$ Hepatitis B rekombinan secara intramuskular pada daerah lengan atas dengan interval waktu 1 bulan. Respons antibodi diukur menggunakan Chemiluminescent Microparticle Immunoassay (CMIA) Architect ausab reagent kit on architect i $1000 \mathrm{sr}$, dilakukan pra dan 28 hari pasca dosis ke-3 vaksinasi. Reaksi lokal dan kejadian sistemik dicatat pada buku catatan harian selama 28 hari pasca tiap imunisasi.

Hasil. Selama periode penelitian didapatkan seratus lima puluh subyek dengan Hbs Ag negatif. Dari jumlah tersebut $112(75,3 \%)$ dengan kadar anti-HBs $<10 \mathrm{IU} / \mathrm{ml}$, dan pasca mendapat 3 dosis imunisasi kekebalan terhadap hepatitis B tercatat pada 95,5\% remaja; GMT682,65 (495,11-941,24) mIU/mL. Tidak ditemukan reaksi serius pasca imunisasi dan semua vaksin dapat diterima dengan baik.

Kesimpulan. Pemberian 3 dosis vaksin Hepatitis B rekombinan memberikan kekebalan yang tinggi dan aman diberikan pada remaja sehat. Sari Pediatri 2013;15(2):87-92.
\end{abstract}

Kata kunci: remaja, vaksin hepatitis B rekombinan

$\mathrm{I}$ nfeksi virus Hepatitis B sampai saat ini masih menjadi masalah kesehatan, diperkirakan lebih dari 2 milyar orang di seluruh dunia pernah terinfeksi virus Hepatitis B. Dari jumlah

\footnotetext{
Alamat korespondensi:

DR. Dr. Eddy Fadlyana, Sp.A(K)., M Kes. Divisi Tumbuh Kembang Fakultas Kedokteran Universitas Padjadjaran Rumah Sakit Dr. Hasan Sadikin Bandung. Jl. Pasteur 38 Bandung 40161. Telp/Fax: (022) 2035957, E-mail: edfadlyana@yahoo.com
}

tersebut, 360 juta terinfeksi kronis sehingga menjadi kelompok risiko tinggi sakit berat sampai kematian. ${ }^{1}$ Saat ini, prevelansi Hepatitis B di Indonesia adalah $9,4 \%$, sehingga dikelompokkan sebagai negara yang mempunyai tingkat kejadian Hepatitis B tinggi. ${ }^{2,3}$ Salah satu upaya pencegahan secara dini, yaitu imunisasi Hepatitis B yang diberikan pada saat segera setelah lahir. ${ }^{4}$ Komplikasi yang dapat ditimbulkan mulai dari asimtomatik hingga menunjukkan penyakit hati kronis disertai komplikasi berupa sirosis hepatis, 
hipertensi portal, karsinoma hepatoselular, dan gagal hepatoselular. ${ }^{4,5}$ Risiko terbentuknya infeksi persisten dan komplikasinya sangat dipengaruhi usia saat terinfeksi, semakin muda saat terinfeksi maka semakin besar kemungkinan menjadi infeksi persisten, bayi yang terinfeksi saat lahir mempunyai risiko tinggi menjadi hepatitis $\mathrm{B}$ persisten. ${ }^{3-5}$

Beberapa penelitian imunisasi Hepatitis B yang sudah dilakukan di Indonesia pada umumnya mengamati kelompok usia dini (bayi) dan masih jarang yang mengamati pada usia remaja. Kelompok remaja menjadi sangat penting karena mereka tidak lama lagi akan menikah dan mempunyai anak. Ibu yang terinfeksi virus Hepatitis B dapat menjadi sumber penularan terhadap anaknya. Tujuan penelitian ini untuk mengetahui respons imun dan keamananannya pasca mendapat 3 dosis vaksin Hepatitis B rekombinan (Bio Farma) yang diberikan pada kelompok remaja sehat dan belum terpapar imunisasi Hepatitis B. Berdasarkan riwayat implementasi program imunisasi Hepatitis B di kota Bandung, diperkirakan kelompok remaja akhir usia 15-18 tahun belum mendapatkan imunisasi Hepatitis B.

\section{Metode}

Penelitian intervensi dilakukan di sekolah menengah atas wilayah koordinasi Puskesmas Garuda Kota Bandung dilaksanakan pada Desember 2011-Juli 2012. Penelitian mendapat persetujuan dari Komtie Etik Fakultas Kedokteran Universitas Padjadjaran, Bandung. ${ }^{6}$ Subjek penelitian terdiri dari remaja sehat berusia 15-18 tahun yang belum pernah mendapatkan imunisasi Hepatitis B. Subjek yang telah terpilih dicatat identitasnya dalam formulir yang telah disediakan sebelumnya. Pada setiap subjek yang memenuhi kriteria inklusi diberikan penjelasan terperinci mengenai penelitian dan menandatangani persetujuan informed consent setelah disetujui, . 7 Setiap subjek mendapat 3 dosis $1,0 \mathrm{~mL}(1,0 \mathrm{ml}=20 \mu \mathrm{g}$ HBsAg$)$ vaksin Hepatitis $B$ rekombinan dengan interval waktu 1 bulan, disuntikkan secara intramuskular di daerah otot deltoid lengan kanan menggunakan jarum no. G23 dengan panjang $25 \mathrm{~mm} .{ }^{8}$ Sampel darah untuk pemeriksaan kadar antibodi diambil pada saat pra dan 28 hari pasca-imunisasi dosis ke-3 Hepatitis B rekombinan. Untuk menilai kadar antibodi spesifik (IgG) serum terhadap Hepatitis B digunakan metode
Chemiluminescent Microparticle Immunoassay (CMIA) Architect ausab reagent kit on architect i $1000 s r .{ }^{9}$ Titer antibodi diekspresikan sebagai geometric mean titre (GMT). Kriteria kekebalan protektif terhadap Hepatitis B apabila titer antibodi terhadap Hepatitis B $>10$ IU/ mL. ${ }^{10}$ Penilaian lama, serta intensitas kejadian lokal dan sistemik yang terjadi dalam 24 jam, 48 jam, 72 jam, dan setiap kejadian merugikan serius sampai 28 hari setiap kali pasca imunisasi dicatat oleh subjek dengan menggunakan buku catatan harian. Penilaian intensitas reaksi lokal menggunakan plastik yang diberi gambar lingkaran (Derajat 1, 2, dan 3). Respons imun pra dan pasca imunisasi dibandingkan dengan uji Wilcoxon untuk data berpasangan, angka kejadian lokal dan sistemik pada tiap pasca imunisasi diuji dengan Mc Nemar. Perbedaan antara proporsi ditentukan dengan uji chi-square atau eksak Fisher. ${ }^{11,12}$

\section{Hasil}

Dilakukan penapisan awal terhadap 155 remaja berusia 15-18 tahun yang belum pernah mendapatkan imunisasi Hepatitis B, 5 di antaranya tidak memenuhi kriteri inklusi. Seratus limapuluh remaja sebagai subjek penelitian dengan hasil $100 \%$ negatif terhadap HBsAg. Hasil pemeriksaan Anti-HBs pra-imunisasi menunjukkan 113 (75,3\%) subjek mempunyai titer anti-HBs < 10 IU/ml (Grup A) dan 37 (24,7\%) subjek mempunyai titer anti-HBs $>10 \mathrm{IU} / \mathrm{mL}$ (Grup B). Karakteristik subjek penelitian tertera pada Tabel 1.

Penilaian terhadap kekebalan yang didapat melalui imunisasi dinilai berdasarkan tolok ukur: a) Persentase subjek yang mempunyai kadar antibodi di atas nilai protektif, b) peningkatan nilai GMT, dan c) peningkatan persentase subjek yang memiliki titer

Tabel 1. Karakteristik subjek penelitian

\begin{tabular}{lccc}
\hline Deskripsi & Grup A & Grup B & Jumlah \\
\hline Subjek (\%) & $113(75,3)$ & $37(24,7)$ & $150(100)$ \\
Jenis kelamin & & & \\
$\quad$ Laki-laki, n(\%) & $24(21,2)$ & $4(10,8)$ & $28(18,7)$ \\
$\quad$ Perempuan, n(\%) & $89(78,8)$ & $33(89,2)$ & $122(81,3)$ \\
Usia (tahun) & & & \\
$\quad$ Rerata \pm SB & $16,8 \pm 0,9$ & $16,6 \pm 0,9$ & $16,7 \pm 0,9$ \\
$\quad$ Min;Maks & 15,$1 ; 19,3$ & 15,$0 ; 18,2$ & 15,$0 ; 19,3$ \\
\hline
\end{tabular}

SB: Simpang Baku

Grup A: Anti Hbs $<10 \mathrm{IU} / \mathrm{mL}$

Grup B: Anti Hbs > $10 \mathrm{IU} / \mathrm{mL}$ 
Eddy Fadlyana dkk: Kekebalan dan keamanan setelah mendapat imunisasi hepatitis B rekombinan

Tabel 2. Respons antibodi terhadap komponen hepatitis B, pra dan pasca-imunisasi hepatitis B

\begin{tabular}{lc}
\hline Deskripsi & Pasca-imunisasi \\
\hline$G M T, \mathrm{mIU} / \mathrm{mL}$ & 682,65 \\
$\quad(\mathrm{IK} 95 \% \mathrm{CI})$ & $(495,11-941,24)$ \\
Anti- HBs $\geq 10 \mathrm{mIU} / \mathrm{mL}$ & \\
$\mathrm{n}$ & 106 \\
$\%$ & 95,5 \\
$\quad(\mathrm{IK} 95 \%)$ & $(89,9-98,1)$ \\
Persentase subjek dengan peningkatan antibodi $\geq 4$ kali & \\
Anti-HBs & $106(95,5)$ \\
(IK 95\%) & $(89,9-98,1)$ \\
\hline
\end{tabular}

GMT: Geometric mean titre

IK: Interval konfidensi

antibodi $\geq 4$ kali. Respons antibodi terhadap komponen Hepatitis B, pra dan pasca-imunisasi Hepatitis B tertera pada Tabel 2.

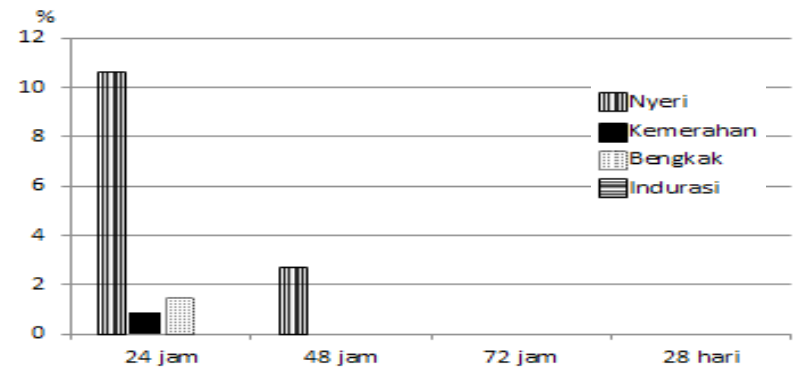

Gambar 1. Reaksi lokal pasca dosis ke-1 imunisasi hepatitis B

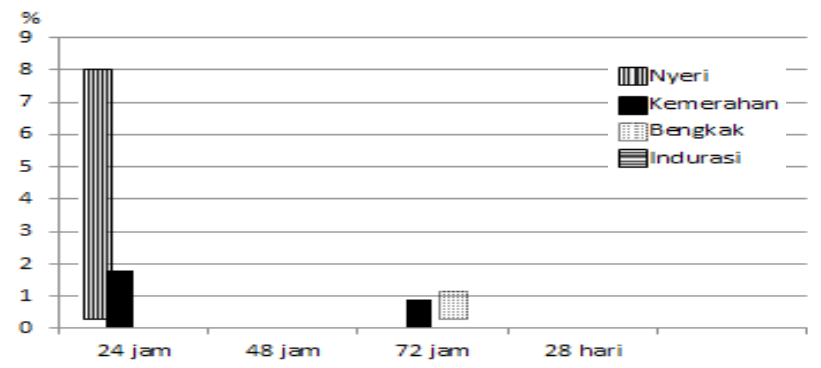

Gambar 2. Reaksi lokal pasca dosis ke-2 imunisasi hepatitis B

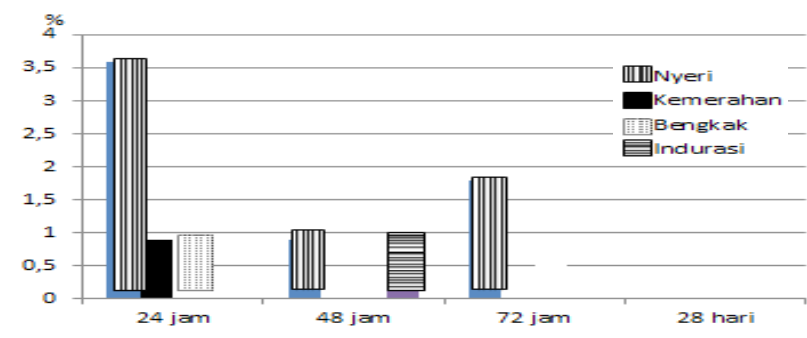

Gambar 3. Reaksi lokal pasca dosis ke-3 imunisasi hepatitis B
Subjek yang mempunyai kadar di atas nilai protektif terhadap hepatitis B ( $\geq 10 \mathrm{IU} / \mathrm{mL})$ sebesar $95,5 \%$. Pasca imunisasi terjadi peningkatan nilai geometric mean titer (GMT) antiHBs dari 0 menjadi $682,65 \mathrm{mIU} / \mathrm{mL}$. Subjek dengan peningkatan titer antibodi $\geq 4$ kali terhadap antiHBs $95,5 \%$ dan $95,5 \%$ yang mengalami perubahan dari seronegatif menjadi seropositif.

Berdasarkan waktu kejadiannya maka reaksi keamanan dinilai dalam 24, 48, 72, dan 72 jam-28 hari pasca imunisasi ke-1, 2, dan 3. Dalam waktu 24 jam pasca-imunisasi terdapat reaksi lokal berupa nyeri pada tempat suntikan pasca-imunisasi ke-1, 2, dan 3 , berturut-turut terdapat pada 10,6\%; 8,0\%; dan $3,5 \%$ subjek. Kemerahan pada tempat suntikan pascaimunisasi ke-1, 2, dan 3, beruturut-turut terdapat pada $0,9 \% ; 1,8 \%$, dan $0,9 \%$ subjek (Gambar 2). Reaksi lokal yang terjadi umumnya bersifat ringan. Reaksi sistemik berupa demam terjadi pasca-imunisasi ke-1, 2 , dan 3, beruturut-turut terdapat pada $0 \% ; 0,9 \%$; dan $0,9 \%$ subjek.

Reaksi lokal yang terjadi selama 48 jam pascaimunisasi adalah nyeri pada tempat suntikan setelah imunisasi ke-1, 2, dan 3, berturut-turut terdapat 2,7\%; 0,9\%; dan 0,9\% subjek. Tidak tercatat adanya kemerahan pada tempat suntikan dan reaksi sistemik setelah imunisasi ke-1, 2, dan 3. Reaksi lokal yang terjadi dalam 72 jam pasca-imunisasi adalah nyeri pada tempat suntikan pasca-imunisasi ke-1, 2, dan 3, berturut-turut terdapat 0\%; 0\%; dan 1,8\% subjek. Kemerahan pada tempat suntikan pasca-imunisasi ke1, 2, dan 3, berturut-turut terdapat pada $0 \% ; 0,9 \%$, dan $0 \%$ subjek. Demam terjadi pasca-imunisasi ke-1, 2 , dan 3, berturut-turut terdapat $0,9 \% ; 1,8 \%$; dan 
$0,9 \%$ subjek. Tidak terdapat reaksi lokal yang terjadi 72 jam-28 hari pasca-imunisasi, namun terdapat demam terjadi pasca-imunisasi ke-1, 2, dan 3, beruturut-turut terdapat pada 3,6\%; $0 \%$; dan $0,9 \%$ subjek.

\section{Pembahasan}

Program imunisasi yang dimulai sejak lahir telah berhasil menurunkan angka penularan virus Hepatitis B di banyak negara yang pada mulanya mempunyai tingkat endemisitas tinggi. Di Indonesia, imunisasi Hepatitis B telah dimulai sejak tahun 1991, dimulai di empat provinsi (Yogyakarta, Jawa Timur, Nusa Tenggara Barat, dan Bali), dan sejak tahun 1997 sudah mencakup seluruh provinsi. Sejak tahun 2004, vaksin hepatitis B rekombinan telah dikombinasikan dengan vaksin DTP menjadi vaksin DTP/HB. ${ }^{13-15}$

Hasil penelitian kami menunjukkan seluruh subjek (100\%) dengan hasil HBs Ag negatif, rendahnya kejadian infeksi ini mungkin akibat program imunisasi yang telah dilakukan dengan cakupan yang tinggi. Di negara dengan tingkat endemisitas sedang atau rendah, masalah penyakit utama berasal dari infeksi akut dan kronis didapat dari anak yang lebih besar, remaja dan dewasa, sebagian besar dari mereka sudah terpapar dengan program imunisasi hepatitis B. Di negara-negara tersebut, implementasi imunisasi rutin pada bayi akan menghasilkan populasi luas yang terproteksi terhadap infeksi hepatitis B sehingga dapat mencegah penjalaran pada berbagai kelompok usia. Hasil penelitian kami tidak berbeda dengan penelitian di India, dengan subjek 112 remaja usia 10-14 tahun dengan hasil $100 \%$ HbsAg negatif. ${ }^{16}$

Pada penelitian kami, sebelum diberikan imunisasi hepatitis B rekombinan ditunjukkan sebagian besar subjek 113/150 (75,3\%) dengan hasil anti $\mathrm{HBsAb}<10$ $\mathrm{IU} / \mathrm{ml}$, kelompok tersebut termasuk risiko tinggi untuk terkena infeksi hepatitis B. Pasca-imunisasi 3 dosis hepatitis B menimbulkan kekebalan di atas nilai proteksi 95,5\% subjek dengan nilai GMT 682,65 (495,11-941,24) IU/ml. Hasil penelitian kami tidak jauh berbeda dengan hasil penelitian sebelumnya yang dilakukan pada bayi, anak, dan remaja. ${ }^{17-19}$ Sebagai tolok ukur keberhasilan pasca-imunisasi Hepatitis B adalah berapa jumlah subjek yang sudah mencapai titer anti-HBs $\geq 10 \mathrm{mIU} / \mathrm{mL}$. Dari beberapa penelitian sebelumnya, ditunjukkan nilai tersebut dianggap sebagai nilai proteksi terhadap infeksi hepatitis B, dan telah didukung oleh banyak ahli. ${ }^{20}$ Respons individual pasca-imunisasi yang tinggi (atau nilai populasi GMT) berhubungan dengan lamanya antibodi menetap. Akan tetapi, banyak penelitian menunjukkan bahwa subjek sehat yang memiliki anti-HBs titer $\geq 10 \mathrm{mIU} /$ $\mathrm{mL}$ pasca imunisasi dapat mempertahankan dalam waktu 5 sampai 12 tahun. Selain itu, sel-sel memori akan tetap melindungi manakala titer antibodi sudah menurun, bahkan apabila di bawah nilai proteksi 10 $\mathrm{mIU} / \mathrm{mL} .^{21-22}$

Lima subjek pada penelitian kami gagal mencapai nilai proteksi infeksi setelah mendapat rangkaian 3 dosis imunisasi Hepatitis B, dan dikelompokkan sebagai non responders. Kelompok tersebut memerlukan tindak lanjut, dan terdapat beberapa strategi pemberian imunissasi tambahan agar mencapai hasil yang optimal. ${ }^{23-26}$ Dari beberapa hasil penelitian ditunjukkan 5\%-10\% subjek sehat akan menjadi kelompok non responders pasca-imunisasi 3 dosis hepatitis B. Kejadian non responders dihubungkan dengan HLA-DR yang berbeda dan kegagalan respons sel $T$ helper (Th), faktor lain adalah cara suntikan, usia, jenis kelamin, dan indeks masa tubuh, tetapi mekanisme pastinya belum dikerahui. Terdapat cukup bukti eksperimental pada tikus bahwa kemampuan untuk menghasilkan antibodi yang tidak berespons terhadap antigen protein yang spesifik dikontrol oleh gen II autosomal kelas histokompatibilitas utama kompleksin. Banyak usaha telah dilakukan untuk mengetahui hubungan non-responders terhadap vaksin hepatitis $B$, penunjukan hubungan korelasi yang signifikan antara tingkat aktifitas IL-2 atau IL-6 dan tingkat serum anti-HBs. ${ }^{21}$ Dalam suatu penelitian terhadap 538 anak yang menerima 3 dosis vaksin hepatitis B rekombinan, terdapat $15,6 \%$ non responder $(<10 \mathrm{mIU} / \mathrm{ml}), 27,7 \%$ hyporesponder $(10-100 \mathrm{mIU} / \mathrm{ml})$, dan $56,7 \%$ good responder $(>100 \mathrm{mIU} / \mathrm{ml}) .{ }^{22}$ Dhaifar ${ }^{22}$ melakukan penelitian evaluasi pengaruh imunisasi tambahan dosis tunggal dan dosis rendah dengan vaksin hepatitis B (HB) rekombinan pada orang Iran sehat non responder setelah imunisasi primer. Hasilnya menunjukkan pada nenonatus non responder dapat menginduksi proteksi anti HBs setelah pemberian 1 dosis tambahan vaksin dengan dosis rendah. Penelitian Kusnandi $\mathrm{dkk}^{26}$ dilakukan dengan pemberian 3 dosis imunisasi tambahan pada bayi sehat Indonesia non respoder, hasilnya menunjukkan seluruh bayi (100\%) memberikan respon di atas nilai proteksi terhadap hepatitis B. Sebuah penelitian telah mengukur respons 
imun 1 bulan pasca pemberian tambahan 1 dosis vaksin hepatitis $\mathrm{B}$ rekombinan pada 18 remaja muda dengan non atau hypo-responder setelah mendapat 3 dosis vaksin hepatitis B rekombinan, semuanya (100\%) memberikan serokonversi, dan $89 \%$ mencapai titier seroproteksi $\geq 10 \mathrm{mIU} / \mathrm{mL}^{23}$

Hasil pengamatan faktor keamanan pada penelitian kami menunjukkan kejadian ikutan pasca-imunisasi terhadap hepatitis B sangat kecil dan pada umumnya ringan. Reaksi lokal yang terjadi dalam 72 jam pada tempat suntikan berupa nyeri terdapat $10,7 \% ; 8,0 \%$, dan $4,6 \%$ subjek yang terjadi secara berturut-turut setelah dosis ke-1, 2 dan 3. Tidak ditemukan reaksi yang serius selama penelitian. Berdasarkan laporan WHO, vaksin hepatitis $B$ sangat aman dan pada umumnya dapat diterima dengan baik. Beberapa masalah ringan pernah dilaporkan: nyeri pada tempat suntikan (1 dari 4) dan suhu $99,9^{\circ} \mathrm{F}$ atau lebih (sampai 1 dari 5 orang). Reaksi alergi berat dilaporkan terjadi sekitar 1 dalam 1,1 juta dosis. ${ }^{27,28}$ Keterbatasan penelitian kami adalah riwayat terpapar imunisasi hepatitis B dikumpulkan berdasarkan pengetahuan orangtua dan rancangan penelitian tidak disertai kontrol.

\section{Kesimpulan}

Pemberian 3 dosis vaksin Hepatitis B memberikan kekebalan yang tinggi dan aman diberikan pada remaja sehat.

\section{Daftar pustaka}

1. Goldstein ST, Zhou F, Hadler SC, Bell BP, Mast EE, Margolis HS. A mathematical model to estimate global hepatitis B disease burden and vaccination impact. Int J Epidemiol 2005;34:1329-39.

2. Departemen Kesehatan RI. Laporan hasil riset kesehatan dasar (Riskesdas 2007). Jakarta: CV Kiat Nusantara; 2008.

3. WHO. Hepatitis B. (diakses tanggal 25 Desember 2012). Diunduh dari: http://www.who.int/csr/disease/hepatitis/ whocdscrrlyo20022/en/index.

4. WHO. Hepatitis B fact sheet. (diakses tanggal 25 Desember 2012.). Diunduh dari: http://www.who.int/mediacentre/ factsheets/fs204/en/.

5. American Academy of Pediatrics. Hepatitis B. Dalam: Pickering LK, Baker CL, Overtruf GD, Prober CG, penyunting., Red Book Report of the Committee on Infectious Diseases, edisi ke-27. Northwest Point Blvd: Elk Grove; 2006. h. 335-55.

6. Fakultas Kedokteran UNPAD-RSUP dr Hasan Sadikin Bandung. Keterangan Persetujuan Komite Etik no 296/FKUPRSHS/KEPK/Kep/EC/2001.

7. Badan Pengawasan Obat dan Makanan. Pedoman cara uji klinik yang baik di Indonesia. Jakarta: BPPOM; 2001.

8. Protectivity and Safety Following Recombinant Hepatitis B (Bio Farma) Vaccine Immunization in Late Adolescents. Protokol Penelitian, versi 1, 0 bulan November 2011.

9. Abbott Architect Ausab. (di akses tanggal 29 Desember 2012) Diunduh dari: http://www.biocanary.com/devices/ pmas/3913.

10. Jack AD, Hall AJ, Maine N, Mendy M, Whittle HC. What level of hepatitis B antibody is protective?. Vaccine 1999; 179:489-92.

11. Pockok SJ. Clinical trials: a practical approach. John Wiley \& Sons Ltd Medical publication;1991.

12. Sastroasmoro S, Ismael S. Dasar-dasar metodologi penelitian klinis. Edisi ke-4. Jakarta: Sagung Seto 2011.

13. Sundoro J. Respons Antibodi dan kejadian ikutan pasca-imunisasi pada bayi sehat yang diimunisasi dengan $\mathrm{DPT} / \mathrm{HB}$ kombinasi dibandingkan DPT $+\mathrm{HB}$ terpisah [disertasi]. Jakarta: Fakultas Kedokteran Universitas Indonesia, 2003.

14. SMF/Bagian Ilmu KesehatanAnak RS Hasan Sadikin Bandung, 2002. Respon antibodi dan kejadian ikutan pasca-imunisasi pada bayi baru lahir yang diimunisasi Hepatitis B rekombinan uniject. Bandung:Laporan penelitian; 2002.

15. Prijanto M. Studi imunogenisitas dan reaktogenisitas vaksin hepatitis B DNA rekombinan (Uniject) buatan Bio Farma di Kabupaten Bogor. Jakarta: Pusat Penelitian \& Pengembangan Pemberantasan Penyakit Badan Penelitian \& Pengembangan Kesehatan; 2001.

16. Bapat S, Joshi D, Naik SS, Bavdekar A, Bhave S, Anand Pandit. Hepatitis B immunization in adolescents girls. Indian Pediatrics 2001; 38:1160-2.

17. Halsey NA, Moulton LH, O’Donovan C, Walcher JR, Yhoms ML, Margolis HS, Krause DS. Hepatitis B vaccine administered to children and adolescents at yearly intervals. Pediatrics 1999;13:1243-7.

18. Greenberg DP, Vadheim CM, Marcy SM, Partridge S, Jing J, Chiu CY, Greene T, Margolis HS, Ward JI. Safety and immunogenicity of a recombinant hepatitis $B$ vaccine administered to infants at 2, 4 and 6 months 
of age. The Kaiser-UCLA Vaccine Study Group. Vaccine 1996;14:811-6.

19. Akram DS, Maqbool S, Khan DS, Jafri R, Randhawa S, Valenzuela-Silva C, Lopez-Saura P. Immunogenicity of a recombinant, yeast-derived, anti-hepatitis-B vaccine after alternative dosage and schedule vaccination in Pakistani children. Vaccine 2005;23:5792-7.

20. Jack AD, Hall AJ, Maine N, Mendy M, Whittle HC. What level of hepatitis $\mathrm{B}$ antibody is protective?.Vaccine 1999;179:489-92.

21. Zuckerman JN. Protective efficacy, immunotherapeutic potential, and safety of hepatitis B vaccines. J Med Virol 2006;78:169-77.

22. Dahifar. H. Immunogenicity of Cuban Hepatitis $\mathrm{B}$ vaccine in Iranian children. Arch Iranian Med 2004;7:89-92.

23. Duval B, Boulianne N, De Serres G, De Wals P, Massé R, Trudeau G. Preadolescent non- and hyporesponders following three doses of hepatitis $\mathrm{B}$ vaccine need only one more dose. Vaccine 2002;20:3632-4.
24. Jacques P, Moens G, Desombere I, Dewijngaert J, LerouxRoels G, Wettendorff M, dkk. The immunogenicity and reactogenicity profile of a candidate hepatitis $B$ vaccine in an adult vaccine non-responder population. Vaccine 2002;20:3644-9.

25. Jafarzadeh A, Zarei S, Shokri F. Low dose revaccination induces robust protective anti-HBs antibody response in the majority of healthy non-responder neonates. Vaccine 2008; 26: 269-76.

26. Rusmil K. Fadlyana E, Bachtiar NS. Booster vaksinasi hepatitis B terhadap anak yang non-reponder. Sari Pediatri 2010;12:88-91.

27. World Health Organization (WHO). Immunization safety surveillance: guideline for managers of immunization programmes on reporting and investigating adverse events following immunization. Manila: WHO; 1999.

28. WHO. Adverse Events Following Immunization (AEFI): causality assessment. World Health Organization. (di akses tanggal 14 November 2012). Diunduh dari: http:// whqlibdoc.who.intlaide-memoirela87773_eng.pdf. 